\title{
Soluble perlecan domain i enhances vascular endothelial growth factor-165 activity and receptor phosphorylation in human bone marrow endothelial cells
}

\author{
Arivalagan Muthusamy ${ }^{1}$, Carlton R Cooper ${ }^{2}$, Ronald R Gomes Jr ${ }^{1 *}$
}

\begin{abstract}
Background: Immobilized recombinant perlecan domain I (PInDI) binds and modulates the activity of heparinbinding growth factors, in vitro. However, activities for PInDI, in solution, have not been reported. In this study, we assessed the ability of soluble forms to modulate vascular endothelial growth factor-165 (VEGF 165 ) enhanced capillary tube-like formation, and VEGF receptor-2 phosphorylation of human bone marrow endothelial cells, in vitro.

Results: In solution, PInDI binds VEGF 165 in a heparan sulfate and pH dependent manner. Capillary tube-like formation is enhanced by exogenous PInDl; however, PInDI/NEGF 165 mixtures combine to enhance formation beyond that stimulated by either PInDI or VEGF 165 alone. PInDI also stimulates VEGF receptor-2 phosphorylation, and mixtures of PInDINEGF 165 reduce the time required for peak VEGF receptor-2 phosphorylation (Tyr-951), and increase Akt phosphorylation. PInDI binds both immobilized neuropilin-1 and VEGF receptor-2, but has a greater affinity for neuropilin-1. PInDI binding to neuropilin-1, but not to VEGF receptor-2 is dependent upon the heparan sulfate chains adorning PInDI. Interestingly, the presence of VEGF 165 but not VEGF 121 significantly enhances PInDI binding to Neuropilin-1 and VEGF receptor-2.

Conclusions: Our observations suggest soluble forms of PInDI are biologically active. Moreover, PInDI heparan sulfate chains alone or together with VEGF 165 can enhance VEGFR-2 signaling and angiogenic events, in vitro. We propose PInDI liberated during basement membrane or extracellular matrix turnover may have similar activities, in vivo.
\end{abstract}

\section{Background}

Perlecan, a heparan sulfate proteoglycan with preferred localization to vascular basement membranes, is comprised of a $\sim 480 \mathrm{kDa}$ protein core with five distinct domains (I - V). Domains II-V share structural homologies with other protein modules [1]. In contrast, $\mathrm{N}$-terminal domain I (PlnDI) is structurally unique. As a $\sim 22 \mathrm{kDa}$ protein core, PlnDI contains 172 amino acid residues that give rise to a sperm protein, enterokinase and agrin (SEA) module localized downstream of three

\footnotetext{
* Correspondence: rgomes@hmc.psu.edu

'Department of Orthopaedics and Rehabilitation, Penn State College of

Medicine, Hershey, Pennsylvania 17033, USA

Full list of author information is available at the end of the article
}

Ser-Asp-Gly motifs that serve as glycosaminoglycan (GAG) attachment sites [2,3].

Through the chondroitin and heparan sulfate GAG chains attached to domain I, perlecan functions as a ligand reservoir for storage, release, and protection of heparin-binding growth factors (reviewed by Whitelock et al., 2008). These interactions allow perlecan to modulate a range of biological functions, including angiogenesis (reviewed by Bix and Iozzo, 2008)[4]. Recent studies suggest immobilized forms of perlecan and PlnDI bind VEGF $_{165}$ to coordinate developmental angiogenesis by modulating $\mathrm{VEGF}_{165} / \mathrm{VEGFR-2}$ signaling $[5,6]$. However, a role for soluble forms of PlnDI and the mechanism(s) by which it modulates $\mathrm{VEGF}_{165} /$ VEGFR-2 signaling is unclear. 
Angiogenic activities of VEGFs are mediated primarily through two receptors [7], VEGFR-1 or fms-like tyrosine kinase 1 [8] and VEGFR-2, also known as kinase domain receptor, and fetal liver kinase 1 [9,10]. Although VEGFR-1 exhibits higher binding affinity for VEGFs, VEGFR-2 dominates VEGF induced mitogenic and angiogenic responses on endothelial cells [11,12]. VEGFR-2 signaling is enhanced by interactions with coreceptors such as heparin/heparan sulfate and Neuropilin 1 (NRP-1) [13]. In addition, VEGF binding to VEGFR-2 and NRP-1 is enhanced by exogenous heparin $[14,15]$. Although the natural cell surface and basement membrane polysaccharide, in vivo, is heparan sulfate, not heparin, few cell surface or extracellular HSPGs have been shown to modulate VEGF/VEGFR interactions $[6,16]$.

Herein, we tested the hypothesis that soluble forms of recombinant PlnDI bind and increase VEGF $_{165}$ /VEGFR2 interactions on human bone marrow endothelial cells, in vitro. Observations from this investigation suggests soluble forms of recombinant PlnDI are biologically active and capable of interacting with components of the VEGFR-2 signaling complex, enhance activity and downstream signaling related to endothelial cell angiogenic processes.

\section{Results}

Purification and biochemical characterization of PInDI

Recombinant PlnDI was purified from conditioned media of HEK 293 EBNA clones as reported previously [17], and further enriched by passage through a Sepharose CL-6B column. This additional step removed high molecular weight contaminants secreted into the serum free media (i.e., full length perlecan). Aliquots of the eluted product were subsequently analyzed by SDSPAGE and Western blotting to identify the GAG chain composition and preparation purity.

In Coomassie blue stained SDS-PAGE gels, undigested samples displayed a broad band between $\sim 45-117 \mathrm{kDa}$ (Figure $1 \mathrm{~A}$, lane 1 ); whereas aliquots pre-treated with a heparinase cocktail yielded a distinct band at $\sim 36 \mathrm{kDa}$, with a broad band between $55-71 \mathrm{kDa}$ (Figure 1A, lane 2). Chondroitinase $\mathrm{ABC}$ pre-digestion yielded a distinct band at $\sim 33$ $\mathrm{kDa}$ and broad band between $45-117 \mathrm{kDa}$ (Figure 1A, lane $3)$. Pre-digestion with both GAG lyases yielded a single band at $33 \mathrm{kDa}$ (Figure 1A, arrow lane 4). The additional bands appearing in Figure 1A, lanes 2-4, represent BSA ( $\varphi$, $\sim 66 \mathrm{kDa})$, chondroitinase $\mathrm{ABC}(\delta, \sim 100 \mathrm{kDa})$, and heparinases I $(\alpha, \sim 43 \mathrm{kDa})$, II $(\beta, \sim 84 \mathrm{kDa})$, and III $(\gamma, \sim 70 \mathrm{kDa})$.

In Alcian blue stained SDS-PAGE gels, undigested samples displayed a broad band between $\sim 45-117 \mathrm{kDa}$

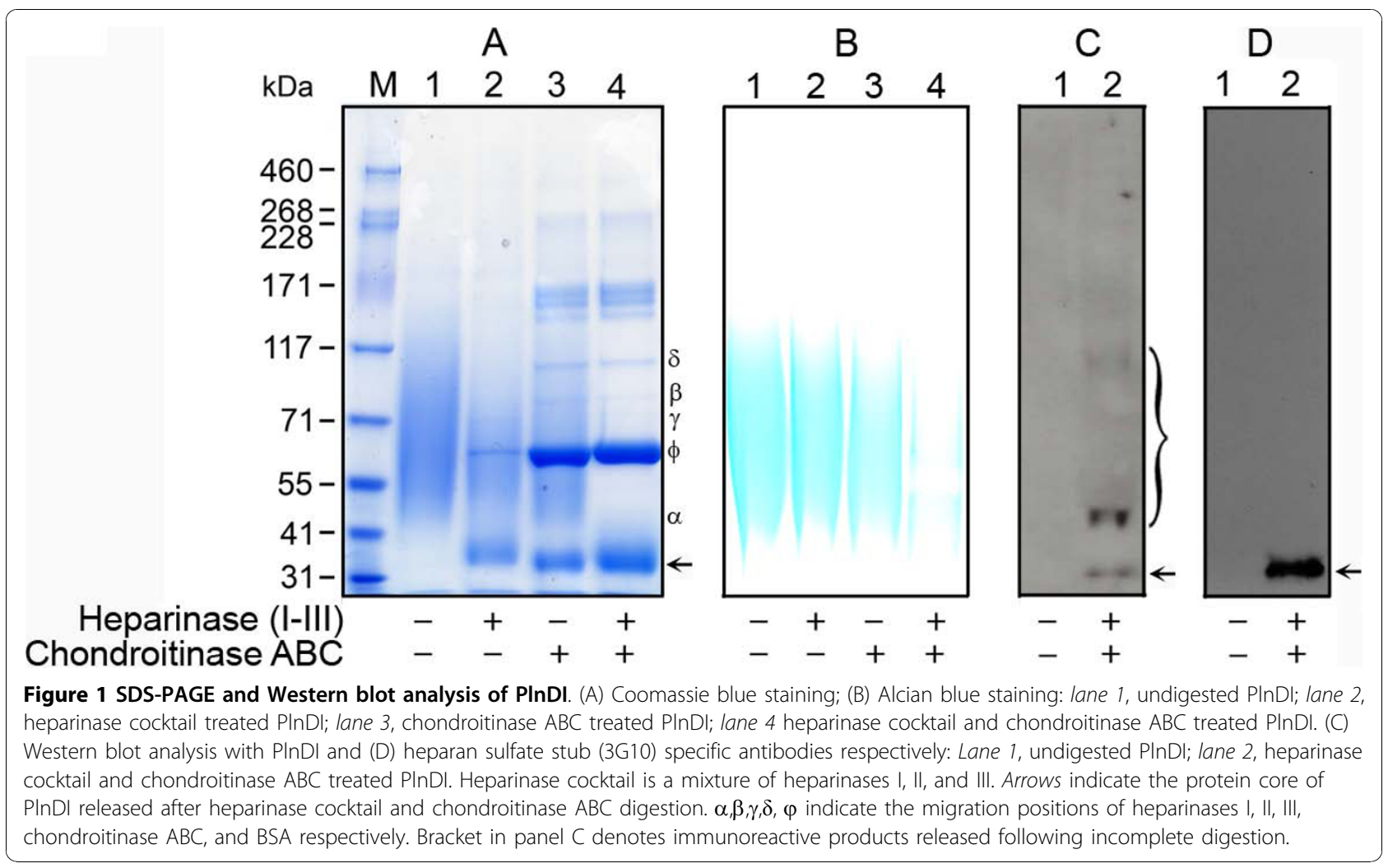


(Figure 1B, lane). Aliquots pre-treated with a heparinase cocktail yielded a broad band between $\sim 50-100 \mathrm{kDa}$ (Figure 1B, lane 2). Chondroitinase $\mathrm{ABC}$ pre-digestion yielded a broad band between $\sim 50-84 \mathrm{kDa}$ (Figure $1 \mathrm{~B}$, lane 3). Pre-digestion with both GAG lyases abolished the majority staining.

The presence of PlnDI was confirmed by Western blotting using anti-PlnDI specific antibodies (CSI-0071) and antibodies (3G10) to anti- $\Delta$-heparan sulfate that recognize heparan sulfate neo-epitopes, generated following heparinase cleavage (arrow Figure 1C and 1D). Neither antibody recognized undigested products; however, anti-PlnDI antibodies recognized partially digested products (bracket in Figure $1 \mathrm{C}$, lane 2) and both antibodies recognize a distinct band at $33 \mathrm{kDa}$ (arrow, Figure $1 \mathrm{C}$ and $1 \mathrm{D})$. The $33 \mathrm{kDa}$ band reflects the domain I core protein adorned with GAG chain linkage residues following heparinase digestion.

Biochemical analysis of PlnDI suggests a protein and uronic acid content of $49 \%$ and $37 \%$, respectively (Table 1). Hexosamine (monosaccharide) compositional analysis revealed PlnDI GAGs are composed predominantly of galactosamine $(60 \%)$ relative to glucosamine $(40 \%)$ (Table 1$)$. The disaccharide composition of purified PlnDI revealed 6-sulfated disaccharide as the major $\triangle \mathrm{di}-\mathrm{CS}$ with lesser amounts of nonsulfated and 4-sulfated disaccharides (Table 2). The major $\Delta$ di-HS derived from PlnDI was nonsulfated and $\Delta$ di$\mathrm{S}_{1}$ with considerable, but lesser amounts of $\Delta \mathrm{di}-\mathrm{S}_{2},-6$ sulfated, -N-sulfated, and -triS disaccharides (Table 2). The HS GAG chains on PlnDI contain approximately 3 fold more 6-O- than 2-O-sulfation.

\section{VEGF $_{165}$ binds to PInDI in a heparan sulfate dependent manner}

To identify requirement(s) for $\mathrm{VEGF}_{165}$ binding to PlnDI, both solid and solution phase binding assays were performed. In solid phase binding assays, immobilized PlnDI binds VEGF 165 in a heparan sulfate dependent manner (Figure 2). Heparinase cocktail treatment of PlnDI, prior to immobilization on nitrocellulose, reduced $\mathrm{VEGF}_{165}$ binding by $\sim 75 \%$ (Figure 2 ). In contrast, pre-digestion with chondroitinase $\mathrm{ABC}$ did not alter VEGF $_{165}$ binding. Studies with the PlnDI protein core, prepared following digestion with a mixture of both enzymes, suggest $\mathrm{VEGF}_{165}$ poorly binds this region. VEGF antibodies do not bind immobilized PlnDI (Figure

Table 1 Biochemical composition of PInDI

\begin{tabular}{llllll}
\hline & \multicolumn{2}{c}{ Composition (\% dry weight) } & & \multicolumn{2}{c}{ Hexosamine (\% mol) } \\
\cline { 6 - 7 } Sample & Protein & Uronic acid & & GalN & GlcN \\
\hline \hline PlnDI & $49(0.37)$ & $37(0.29)$ & $60(0.87)$ & $40(0.88)$ \\
\hline
\end{tabular}

Data are presented as the mean of three independent experiments \pm (SEM).
2). In competitive inhibition assays, heparin $[0.25 \mu \mathrm{g} / \mathrm{ml}]$ prevented $\sim 80 \%$ of $\mathrm{VEGF}_{165}$ binding to PlnDI (Figure 2).

In solution, requirements for $\mathrm{VEGF}_{165}$ binding to PlnDI were similar, but the capacity of binding demonstrated $\mathrm{pH}$ dependence (Figure 3A). When the $\mathrm{pH}$ of solution was reduced from 8.0 to 7.0 then $6.0, \mathrm{VEGF}_{165}$ binding was reduced by $50 \%$ and $80 \%$, respectively (Figure $3 \mathrm{~A})$. To identify $\mathrm{VEGF}_{165}$ specific binding, the background binding of $\mathrm{VEGF}_{165}$ to nitrocellulose was subtracted from total bound to PlnDI [18]. Employing this approach, PlnDI-HS chains account for nearly all VEGF $_{165}$ binding, and the presence of CS chains masks VEGF $_{165}$ interaction with HS (Figure $3 \mathrm{~B}$ ). In panel B, neutral $\mathrm{pH}$ was chosen to more closely reflect tissue culture conditions of subsequent experiments.

\section{PInDI modulation of VEGF ${ }_{165}$ bio-activity}

To identify a role for PlnDI in modulating $\mathrm{VEGF}_{165}$ activity in vitro, human bone marrow endothelial cells were employed in two independent assays: 1) VEGF V65- $^{-}$ enhanced capillary tube-like formation; 2) $\mathrm{VEGF}_{165^{-}}$ enhanced phosphorylation of VEGFR-2. In capillary tube-like formation assays, the ability of bone marrow endothelial cells to form tube-like structures in the presence of exogenous $\mathrm{VEGF}_{165}+/$ - PlnDI was quantified. Under serum free conditions, the addition of soluble VEGF $_{165}$ (positive control) and PlnDI demonstrated dose dependent increases in lengths of tube-like structures formed (Figure 4A-B and 1F). Optimal concentrations for $\mathrm{VEGF}_{165}[20 \mathrm{ng} / \mathrm{ml}]$ and PlnDI $[12.5 \mu \mathrm{g} / \mathrm{ml}]$ increased tube-like formation $35 \%$ and $24 \%$, respectively.

Studies employing PlnDI, pre-treated with either chondroitinase $\mathrm{ABC}$ and/or a heparinase cocktail suggests the ability of PlnDI to enhance tube-like formation is HS chain dependent (Figure 4C). Moreover, PlnDI activity is further enhanced when its CS chains are removed. Interestingly, PlnDI/VEGF 165 mixtures combine to enhance tube-like formation $16 \%$ relative to VEGF $_{165}$ alone (Figure 4D). The synergy between PlnDI and VEGF VE5 $_{165}$ is PlnDI-HS chain dependent (Figure 4D). PlnDI protein core/VEGF 165 mixtures produce tube-like structures indifferent from those by $\mathrm{VEGF}_{165}$ alone. Unexpectedly, heparin/VEGF 165 mixtures do not synergize in this system (Figure $4 \mathrm{E}$ ).

Since the presence of endogenous cell surface HS complicates the studies above, experiments employing bone marrow endothelial cells without cell surface HS were performed. Under these conditions, $\mathrm{VEGF}_{165}$ and PlnDI enhance tube-like formation (Figure 5); however, PlnDI/VEGF 165 mixtures did not combine to further enhance the lengths of tube-like structures. Subsequent dose response studies suggested elevated concentrations of $\mathrm{VEGF}_{165}$ and PlnDI are required for maximal activity. Increasing PlnDI concentration two fold $[25.0 \mu \mathrm{g} / \mathrm{ml}]$ 
Table 2 Disaccharide composition of Chondroitin and Heparan sulfate chains of PInDI

\begin{tabular}{|c|c|c|c|c|c|c|c|c|c|}
\hline \multirow[b]{2}{*}{ Sample } & \multicolumn{3}{|c|}{ Chondroitin sulfate $(\% \mathrm{~mol})$} & \multicolumn{6}{|c|}{$\underline{\text { Heparan sulfate }(\% \mathrm{~mol})}$} \\
\hline & $\Delta \mathrm{di}-0 \mathrm{~S}$ & $\underline{\Delta \mathrm{di}-4 \mathrm{~S}}$ & $\Delta \mathrm{di}-6 \mathrm{~S}$ & $\Delta \mathrm{di}-0 \mathrm{~S}$ & $\Delta$ di-NS & $\Delta$ di-6S & $\underline{\Delta \mathrm{di}-\mathrm{S}_{1}}$ & $\Delta \mathrm{di}-\mathrm{S}_{2}$ & $\Delta$ di-triS \\
\hline $\mathrm{PInDI}$ & $34(0.88)$ & $28(0.88)$ & $38(1.45)$ & $31(1.15)$ & $2(0.88)$ & $9(1.76)$ & $40(1.73)$ & $15(1.45)$ & $3(1.09)$ \\
\hline
\end{tabular}

Data are presented as the mean of three independent experiments \pm (SEM).

restored synergy with $\mathrm{VEGF}_{165}$ in a PlnDI-HS chain dependent manner (Figure 5).

Because the role of HS in heparin-binding growth factor activity may involve interactions between HS, ligand, and cell surface receptors, the ability of PlnDI-HS to modulate $\mathrm{VEGF}_{165}$-induced VEGFR-2 tyrosine phosphorylation was investigated by Western blot using VEGFR-2 (Tyr-951) specific antibodies. VEGFR-2 phosphorylation at Tyr-951 results in recruitment of several adapter proteins whose subsequent downstream signaling supports endothelial cell survival and migration [19]. To perform these studies, we employed bone marrow endothelial cells whose cell surface HS were first removed by exposure to heparinases. Under these conditions, the exogenous addition of PlnDI and $\mathrm{VEGF}_{165}$ (positive control) enhanced VEGFR-2 phosphorylation at Tyr-951 (Figure 6A-B). The signal intensity of phosphorylation increased over time, peaked after ten minutes, then returned to control levels after 20 minutes (Figure 6A-B). The addition of PlnDI, adorned with only HS chains, enhances Tyr-951 phosphorylation $\sim 3$ fold relative to intact PlnDI (Figure $6 \mathrm{C}$ ). Studies employing PlnDI preparations pre-treated with mixtures of chondroitinase $\mathrm{ABC}$ and heparinase enzymes did not completely attenuate phosphorylation (Figure 6C). Heparin

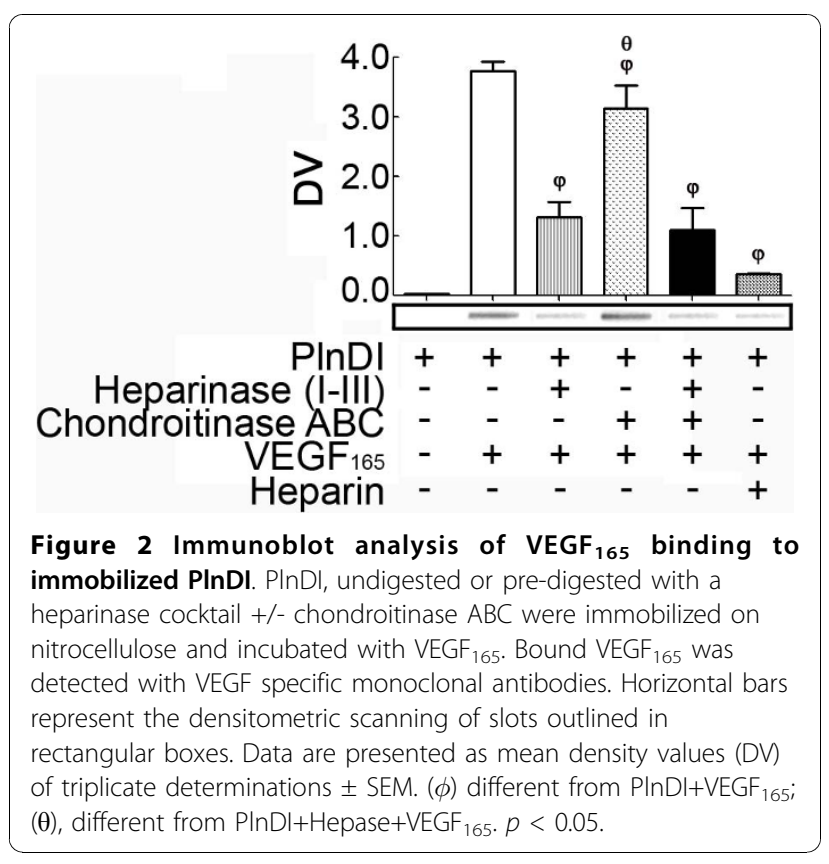

addition (positive control) also enhanced VEGFR-2 phosphorylation (Figure 6C).

Relative to either alone, PlnDI/VEGF 165 mixtures stimulate peak phosphorylation after only 2.5 minutes (Figure 7A vs. 6A-B). To identify the role of PlnDI-HS in modulating VEGF 165 induced VEGFR-2 phosphorylation at Tyr-951, PlnDI preparations adorned with either CS, HS, or without GAGs were pre-mixed with VEGF $_{165}$. The absence of HS chains on PlnDI reduced the signal intensity of phosphorylation 43\% (Figure 7B). In contrast, preparations decorated only with HS chains enhance the signal intensity of phosphorylation $\sim 3$ fold (Figure 7B). The absence of CS and HS chains did not completely reduce the intensity of phosphorylation relative to control (VEGF 165$)$.

To determine if PlnDI/VEGF 165 enhanced VEGFR-2 phosphorylation also promotes downstream signaling, blots were stripped then re-probed with antibodies specific for total and phosphorylated forms of Akt. PlnDI/ VEGF $_{165}$ mixtures enhance the signal intensity of phosphorylated Akt $\sim 4$ fold, relative to $\mathrm{VEGF}_{165}$ alone (Figure $7 \mathrm{C}$ ), and $\sim 40 \%$ of this activity is PlnDI-HS chain dependent.

Since PlnDI may modulate phosphorylation via direct interactions with VEGFR-2 or a candidate co-receptor, we performed binding studies with immobilized recombinant VEGFR-2 and NRP-1. PlnDI binds VEGFR-2 and NRP-1 (Figure 8A-B); however, a higher percentage of PlnDI binds NRP-1. The presence of VEGF 165 but not VEGF $_{121}$ (negative control) enhances PlnDI binding to VEGFR-2 (27\%) and NRP-1 (13\%). The presence of heparin $[1 \mu \mathrm{g} / \mathrm{ml}]$ reduces PlnDI binding to NRP-1 more than $60 \%$. In contrast, PlnDI binding to VEGFR-2 was poorly competed away by heparin (Figure $8 \mathrm{~A}-\mathrm{B}$ ).

\section{Discussion}

For the first time, we have characterized the ability of recombinant PlnDI to bind $\mathrm{VEGF}_{165}$ and modulate its angiogenic activity, in vitro. We have shown that soluble forms of PlnDI are capable of modulating VEGFR-2 phosphorylation, as well as $\mathrm{VEGF}_{165}$-induced phosphorylation of VEGFR-2, and that the heparan sulfate glycosaminoglycan chains adorning PlnDI are important for these activities. Together, our observations suggest soluble forms of PlnDI may form and/or stabilize a complex between VEGF 165 , NRP-1, and VEGFR-2 to enhance angiogenic events and VEGFR-2 signaling in human bone marrow endothelial cells (summarized in Figure 9). 
A

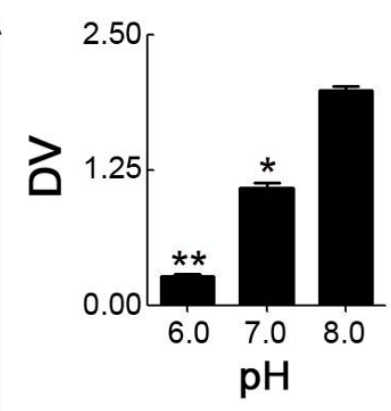

B

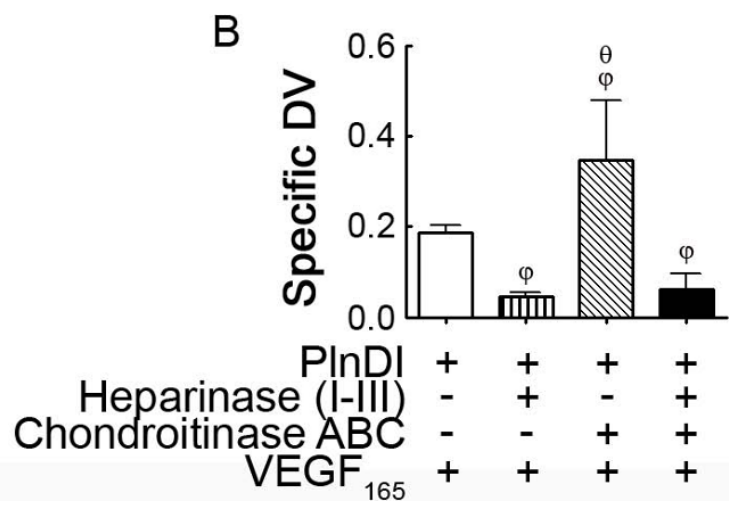

Figure $\mathbf{3}$ VEGF $_{\mathbf{1 6 5}}$ binding to PInDI in solution is $\mathbf{p H}$ dependent. PInDI pre-incubated with VEGF 165 in 25 mM HEPES (pH 6.0, 7.0, or 8.0) was immobilized on nitrocellulose. VEGF 165 bound to PInDI was detected with VEGF specific monoclonal antibodies. (A) pH dependent binding of VEGF $_{165}$ to PInDI. (B) The requirement of $\mathrm{CS}$ and HS chains for VEGF 165 binding to PInDI (pH 7.0). Data are presented as mean specific density values (DV) of triplicate determinations \pm SEM. Specific binding was determined by subtracting the background binding of VEGF 165 to nitrocellulose from total bound. $\left(^{*}\right)$ different from $\mathrm{pH} 8.0 ;\left(^{* *}\right)$ different from $\mathrm{pH} 7.0$; $(\phi)$ different from PInDI+VEGF $165 ;(\theta)$, different from PInDI +Hepase+VEGF $165 . p<0.05$.

In contrast to our previous reports $[17,20]$, the purity of PlnDI employed in the present investigation was enhanced by passage through a Sepharose CL-6B column. SDS-PAGE, Western blot and monosaccharide analysis suggest the molecular weight and GAG chain composition of PlnDI are similar to species previously characterized [20,21]. Moreover, these observations predict our preparation contains at least two species of PlnDI: one adorning predominately CS and the other predominately HS chains. Interestingly, the CS and HS disaccharide composition of PlnDI reported herein is different from species recently characterized by Whitelock et al. [22], as well as that reported for full length perlecan purified from bovine rib growth plate cartilage, HUAEC and RT101 cell lines [23-25]. These differences could be due to: 1) cell culture conditions; 2) approaches for purification; and 3) approaches employed for disaccharide analysis. Regardless, since fewer 4-sulfated CS residues and more 2 -sulfated and 6-sulfated HS residues were identified it is reasonable to conclude that the function of PlnDI employed herein is distinct from forms previously reported. Indeed, subtle variations in HS substructure profoundly affect heparin-binding growth factor and receptor interactions, and thus the activity of perlecan [26-28].

While the role(s) of HS chains on perlecan have been most widely investigated with regard to regulation of FGF-2 activity [29,30], few studies have reported on perlecan-VEGF 165 interactions [5,6,22]. Moreover, the GAG modifications required specifically for perlecan-VEGF 165 interactions have not been described. Nevertheless, studies with heparin/HS suggest 2-O- and 6-O- sulfation is important for VEGF binding and activity [31-33]. Although the abundance of 2-O- and 6-O-sulfation on

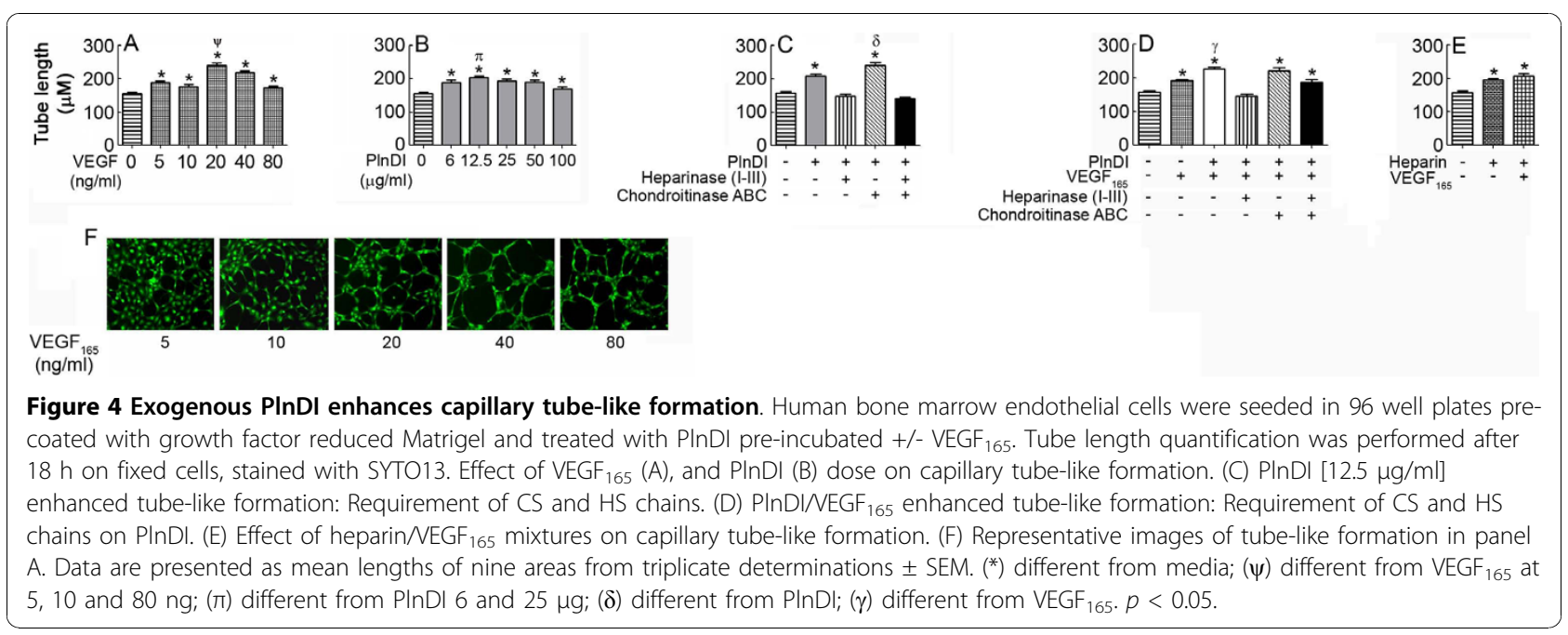




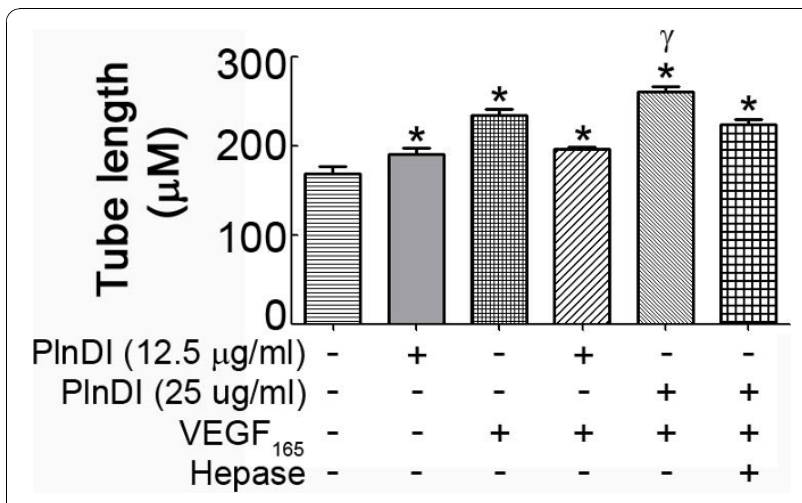

Figure 5 In the absence of cell surface heparan sulfate increased PInDI concentrations restore synergy with VEGF $_{165}$. Human bone marrow endothelial cells, in suspension, were treated with a heparinase cocktail, washed, then incubated with PInDI [12.5 $\mu \mathrm{g} / \mathrm{ml}]+/-V E_{165}[20 \mathrm{ng} / \mathrm{ml}]$ for 30 minutes prior to seeding in wells pre-coated with growth factor reduced Matrigel. After $18 \mathrm{~h}$ cells were fixed, stained with SYTO13, and tube length quantified. Both PInDI and $\mathrm{VEGF}_{165}$ enhance capillary tube-like formation. A two fold increase in $\mathrm{PlnDl}$ concentration $[25 \mu \mathrm{g} / \mathrm{ml}]$ is required for synergy with $V_{E G F}{ }_{165}$. Data are presented as the mean lengths from nine areas of triplicate determinations \pm SEM. $\left(^{*}\right)$ different from media; $(\gamma)$ different from VEGF $165 . p<0.05$.

PlnDI-HS suggests it harbors the capacity to interact with $\mathrm{VEGF}_{165}$, a correlation between $\mathrm{VEGF}_{165}$ affinity and abundance of a particular disaccharide or the overall level of HS sulfation has not been observed [31]. Thus, growth factor binding is likely determined by HS domain organization (i.e., length of sulfation and transition domains, as well as their placement along the chain). Since HS chains on recombinant PInDI are likely to be short $(8-10 \mathrm{kDa})$ relative to those on tumorderived perlecan $(30-70 \mathrm{kDa})[21,34,35]$, we predict 48 residues comprise a single HS chain on PlnDI (based on the molecular weight of repeating units of glucuronic acid and $N$-acetylglucosamine). Moreover, since six or seven oligosaccharide residues are sufficient to fully occupy the HS binding site for $\operatorname{VEGF}_{165}$ [31], we further predict that six VEGF $_{165}$ binding sites (maximally) may be available on each HS chain attached to PlnDI.

The HS dependent binding of $\mathrm{VEGF}_{165}$ to immobilized PlnDI described herein is consistent with recent reports [5,6]. In contrast, a new communication has reported PlnDI does not bind immobilized VEGF 165 [36]. We suspect the concentration and/or the disaccharide composition of PlnDI employed therein may account for the contrasting observations. Our studies with PlnDI in solution suggest $\mathrm{VEGF}_{165}$ binding to PlnDI in solution is not only HS but $\mathrm{pH}$ dependent. The marked reduction in $\mathrm{VEGF}_{165}$ binding to PlnDI under acidic conditions, a novel observation, is consistent with previous publications describing the attenuation of $\mathrm{VEGF}_{165}$ binding with low concentrations of heparin under acidic conditions, and its potentiation at neutral $\mathrm{pH}[14,37]$.

To identify the ability of soluble, exogenous PlnDI to modulate $\mathrm{VEGF}_{165}$ activity, in vitro, tube-like formation studies were performed with human bone marrow endothelial cells seeded on growth factor reduced (GFR) Matrigel. We hypothesized that PlnDI/VEGF 165 mixtures would enhance the lengths of tube-like structures formed over $\mathrm{VEGF}_{165}$ alone. While our observations support this hypothesis, we were surprised that PlnDI addition, alone, also enhanced the length of tube-like structures. Given our experimental approach, the enhancement of tube-like formation by soluble, exogenous, PlnDI may also reflect interactions with other matrix molecules (i.e., fibronectin and laminin) and heparin-binding growth factors present in GFR Matrigel reported to interact with PlnDI [38]. This possibility, however, should not discount the ability of exogenous PlnDI to interact directly with human bone marrow endothelial cells, or the possibility that the presence of heparin-binding molecules and growth factors may even mask the full activity of PlnDI.

Interestingly, under conditions where bone marrow endothelial cells were pre-treated with a heparinase cocktail, the additive effect of PlnDI/VEGF 165 mixtures on tube-like formation was not observed unless the concentration of PlnDI was increased two fold. While these observations suggest PlnDI-HS chains can modulate VEGF $_{165}$ activity, in vitro, heparin/VEGF 165 mixtures (positive control [14,32]), did yield similar results. We remain puzzled by this observation since heparin/ VEGF $_{165}$ mixtures combine to enhance VEGFR-2 phosphorylation, suggesting heparin is active in our system.

At the cellular/receptor level, we analyzed VEGFR-2 auto-phosphorylation to identify requirements for PlnDI modulation of $\mathrm{VEGF}_{165}$ activity, in vitro. While both VEGFR-1 and VEGFR-2 contribute to VEGF induced signals, VEGFR-2 dominates VEGF induced mitogenic and angiogenic responses in endothelial cells [11,12]. Of the six tyrosine phosphorylation sites identified on the intracellular domain of VEGFR-2, we report on one associated with endothelial cell survival and migration [39]. Together, our observations suggest exogenous soluble PlnDI, alone, can stimulate VEGFR-2 phosphorylation at Tyr-951. Moreover, PlnDI fragments harboring only $\mathrm{HS}$ chains further enhance VEGFR-2 phosphorylation, suggesting the presence of CS chains masks activity. These studies importantly extend those recently reported for full length perlecan [6] by demonstrating delivery of PlnDI or co-delivery with $\mathrm{VEGF}_{165}$ are sufficient to enhance VEGFR-2 phosphorylation, and promote downstream signaling (i.e., increased Akt phosphorylation). Given our approach (i.e., the use of cells in suspension), our observations suggest PlnDI/VEGF 165 

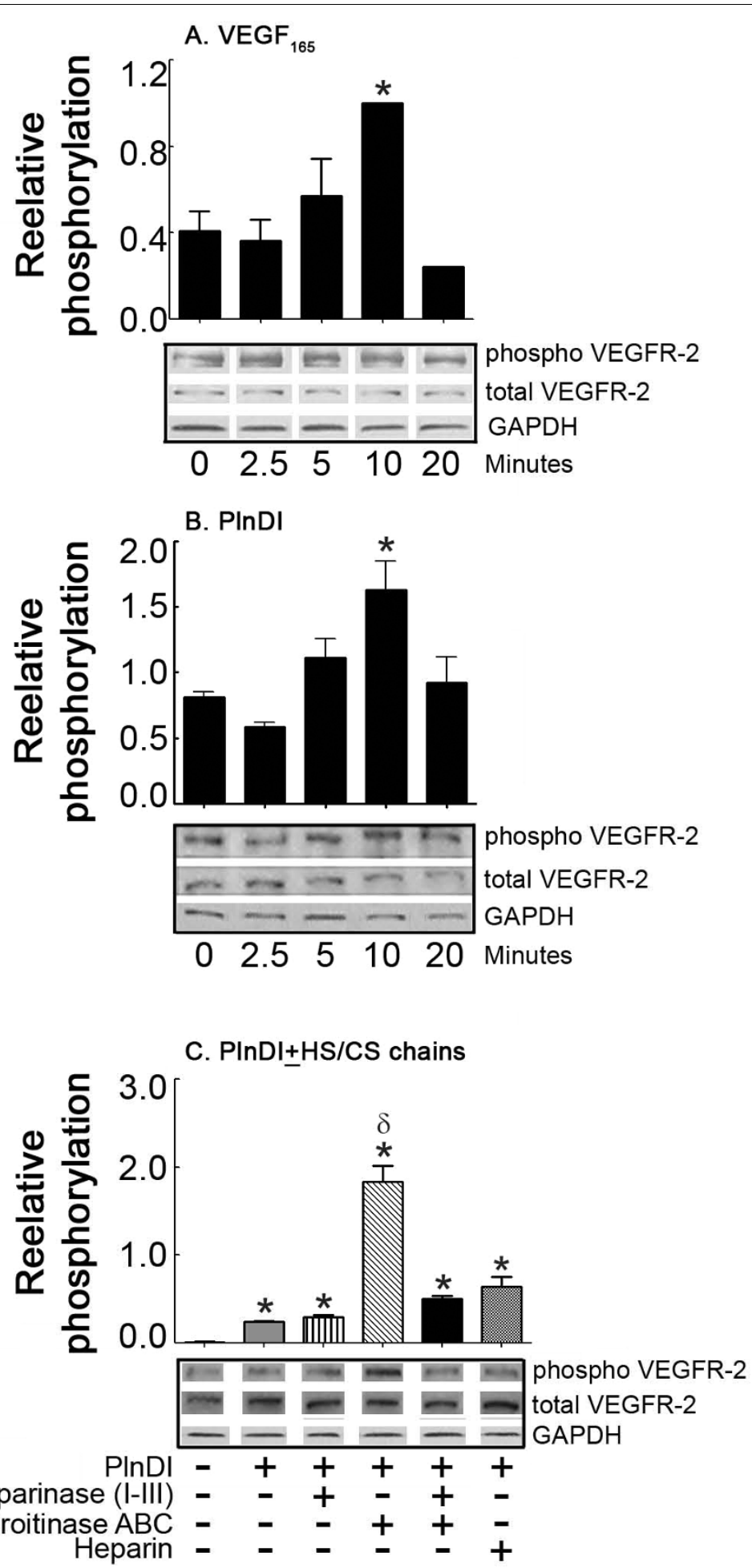

Figure 6 PInDI stimulates VEGFR-2 (Tyr-951) phosphorylation. Human bone marrow endothelial cells without cell surface HS were incubated with $\mathrm{VEGF}_{165}$ or PInDI for 0, 2, 5, 10 and 20 minutes. Cell lysates were analyzed for VEGFR-2 phosphorylation by Western blot using anti-phospho and total VEGFR-2 tyrosine residue 951 specific antibodies. Time dependant increase in VEGFR-2 phosphorylation induced by: (A) VEGF $_{165}$ and (B) PInDI. (C) PInDI induced VEGFR-2 phosphorylation: Requirement for CS and HS chains. Exogenous heparin served as a positive control and GAPDH as loading control. Horizontal bars represent the densitometric scanning of bands outlined in rectangular boxes. Data are presented as the mean density values (DV) from triplicate determinations \pm SEM. $\left(^{*}\right)$ different from 0 min or media. $(\delta)$ different from PInDI. $p<0.05$. 
A

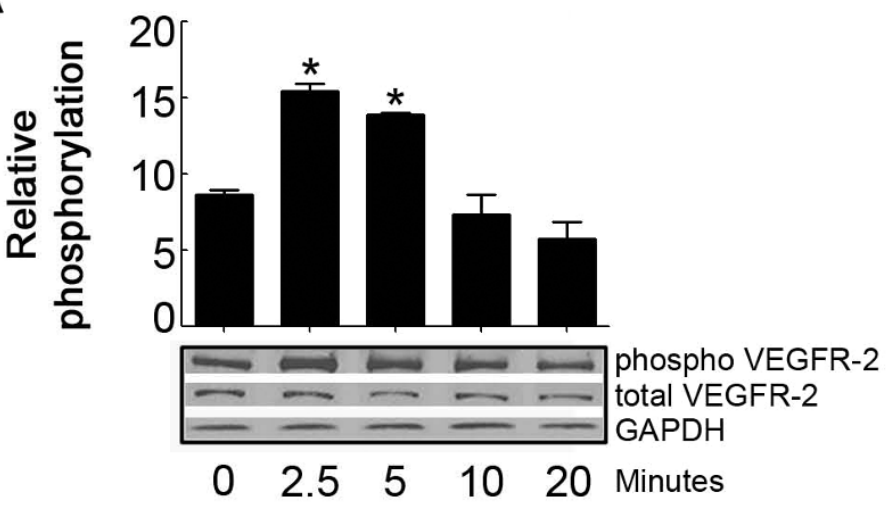

B

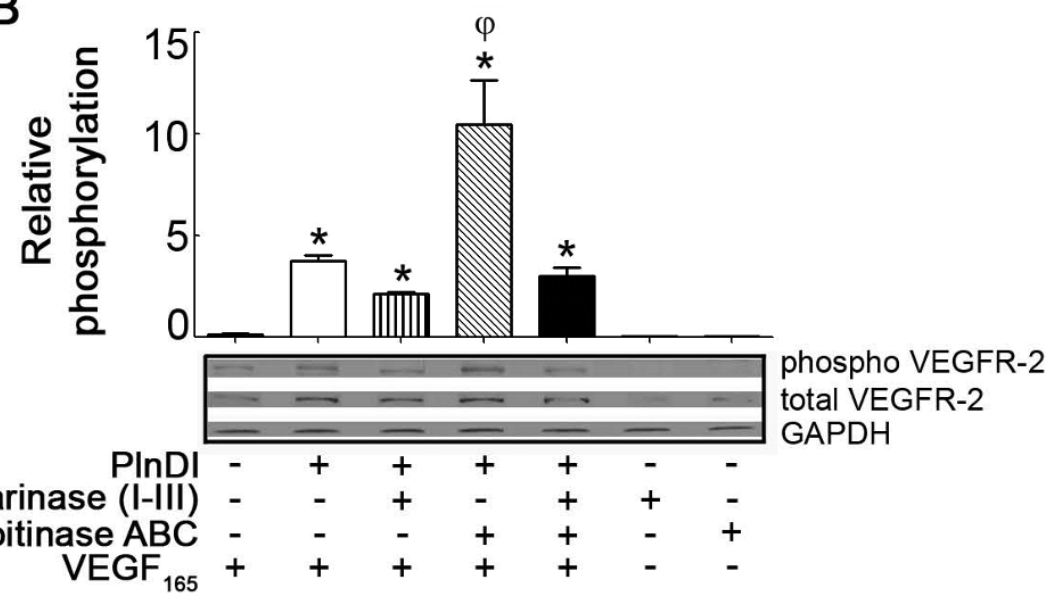

C
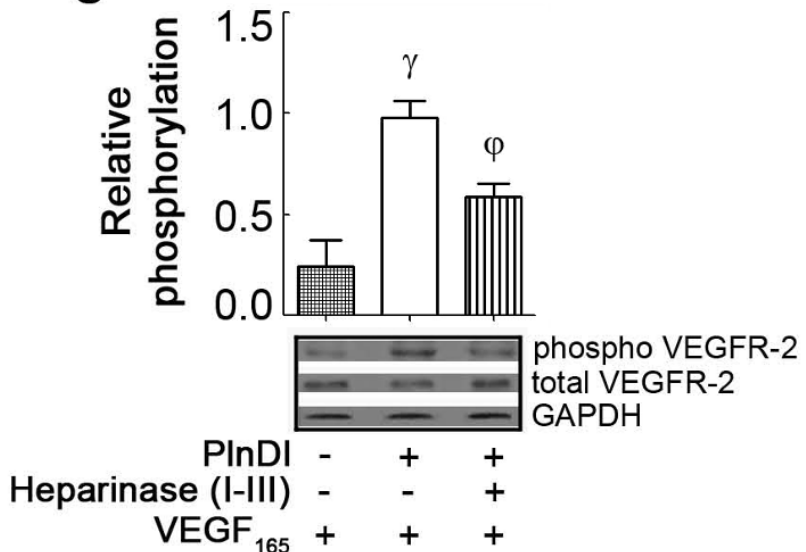

Figure 7 PInDI/VEGF ${ }_{165}$ mixtures enhance VEGFR-2 (Tyr-951) phosphorylation. Human bone marrow endothelial cells without cell surface HS were incubated with PInDINEGF 165 mixtures for either 0, 2, 5, 10, or 20 min. Cell lysates were analyzed for VEGFR-2 (A and B) or Akt (C) phosphorylation by Western blot using anti-phospho and total VEGFR-2 (tyrosine residue 951) and Akt specific antibodies. (B) PInDI/VEGF 165 enhanced VEGFR-2 phosphorylation (at min 2.5): Requirement of CS and HS chains on PInDI. Horizontal bars represent the densitometric scanning of bands outlined in rectangular boxes. GAPDH was assessed as a loading control. Data are presented as the mean of three independent experiments \pm SEM. $\left(^{*}\right)$ different from 0 min; $(\gamma)$ different from VEGF $165 ;(\phi)$ different from PInDI+VEGF $165 . p<0.05$. 


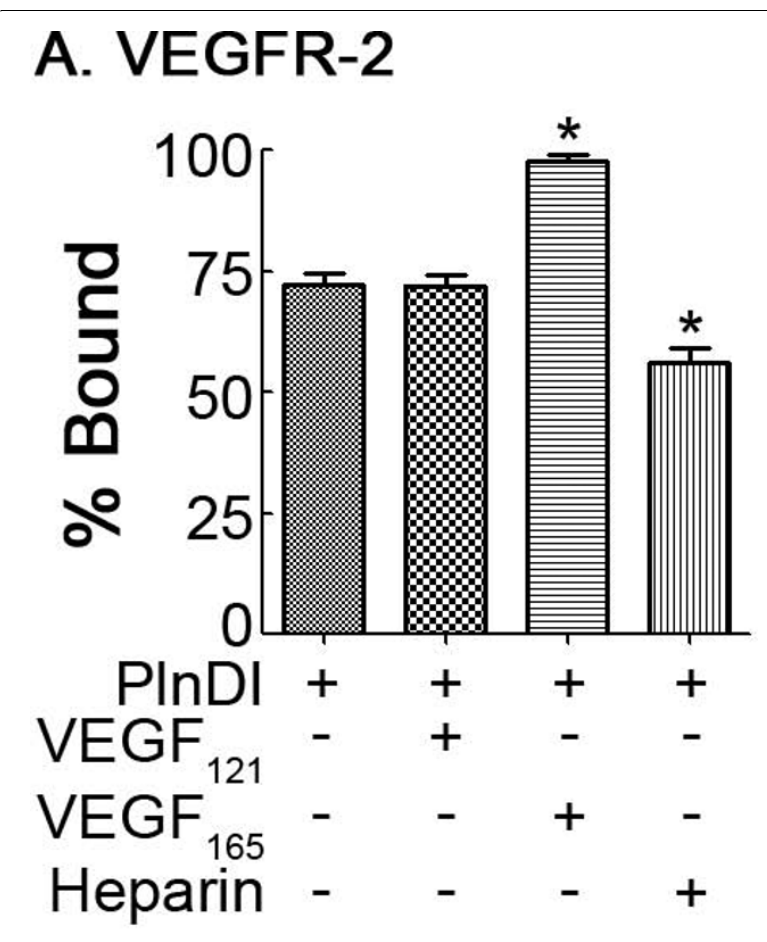

\section{B. NRP-1}

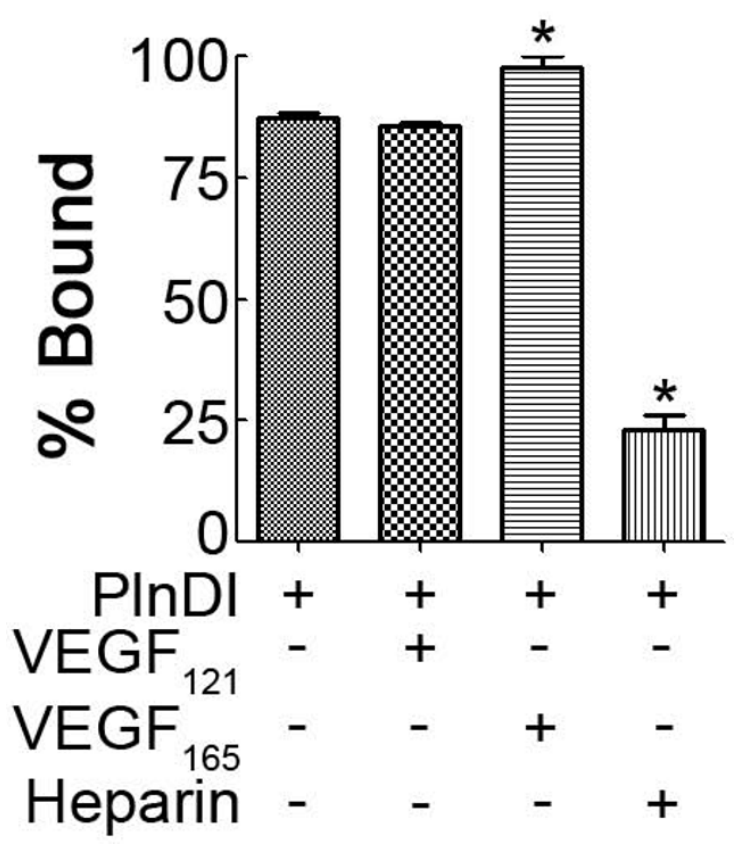

Figure 8 PInDI binds NRP-1 and VEGFR-2. Recombinant NRP-1 and VEGFR-2 coated plates were incubated with PInDI +/- VEGF 165 or VEGF ${ }_{121}$. PInDI binding was detected and quantified using an ELISA based approach that employed anti-PInDI specific antibodies. For competitive inhibition assays, PInDI was pre-incubated with heparin $[1 \mu \mathrm{g} / \mathrm{ml}$. (A) PInDI binding to VEGFR-2. (B) PInDI binding to NRP-1. Data are presented as a percentage of total bound. $\left(^{*}\right)$ different from PInDI. $p<0.05$. mixtures enhance survival signaling (increased Akt phosphorylation) of human bone marrow endothelial cells, in vitro. Consistent with this conclusion, our unpublished observations suggest VEGFR-2 phosphorylation at Tyr-1175 and Tyr 1214, and phosphorylation of p38 MAPK, Erk1/2 (events associated with endothelial cell proliferative and migratory states) [39], are unaltered.

Finally, to determine if PlnDI has the capacity to bind and modulate the activity of VEGFR-2 directly, we performed PlnDI binding studies against immobilized VEGFR-2, and NRP-1. Outcomes from these studies suggest PlnDI-HS chains, similar to heparin/HS, harbor the capacity to interact with VEGFRs and co-receptors $[15,32,40]$, and enhance VEGFR-2 signaling [41]. We suspect PlnDI-HS chain binding to NRP-1 occurs via its heparin binding domain [15]. In contrast, PlnDI binding to VEGFR-2 is less dependent on HS chains. Heparin concentrations up to $[100 \mu \mathrm{g} / \mathrm{ml}]$ did not appreciably alter binding (unpublished observations). Interestingly, the presence of VEGF ${ }_{165}$ enhances PlnDI binding to VEGFR-2, suggesting the formation of a complex between PlnDI/ VEGF165/VEGFR-2 is possible. Our observations also suggest that modulation of VEGFR-2 signaling by PlnDI may involve complex interactions with more than one ligand.

\section{Conclusion}

The findings presented herein demonstrate exogenous, soluble, recombinant PlnDI is sufficient to bind and modulate the activity of the VEGFR-2 signaling complex via $\mathrm{HS}$ interactions, in vitro. Moreover, PlnDI may have activities independent of those with heparin-binding growth factors in supporting tube-like formation, in vitro. Figure 9 provides a simplified visual depiction of how PlnDI may impact angiogenic events in the absence or presence of $V_{E G F} 165$. PlnDI unbound or bound to VEGF $_{165}$ is liberated via cleavage within its SEA module [42] or the single immunoglobulin G-like region of domain II $[43,44]$ during matrix turnover, wound healing, or disease progression. In the absence of $\mathrm{VEGF}_{165}$, PlnDIHS may bind to NRP-1, VEGFR-2, or support complex formation with both to signal downstream angiogenic events. When VEGF $_{165}$ is present PlnDI interactions with NRP-1 and VEGFR-2 are optimized, leading to enhanced downstream signaling and angiogenesis.

\section{Methods}

\section{Materials}

Recombinant human VEGF ${ }_{165}$, VEGFR-2, NRP-1, and anti-VEGF 165 monoclonal antibodies were procured from R\&D systems, Inc. (Minneapolis, MN). Growth factor reduced Matrigel was purchased from BD Biosciences (San Jose, CA). Goat polyclonal antibodies to GAPDH were purchased from Genscript (Piscataway, 


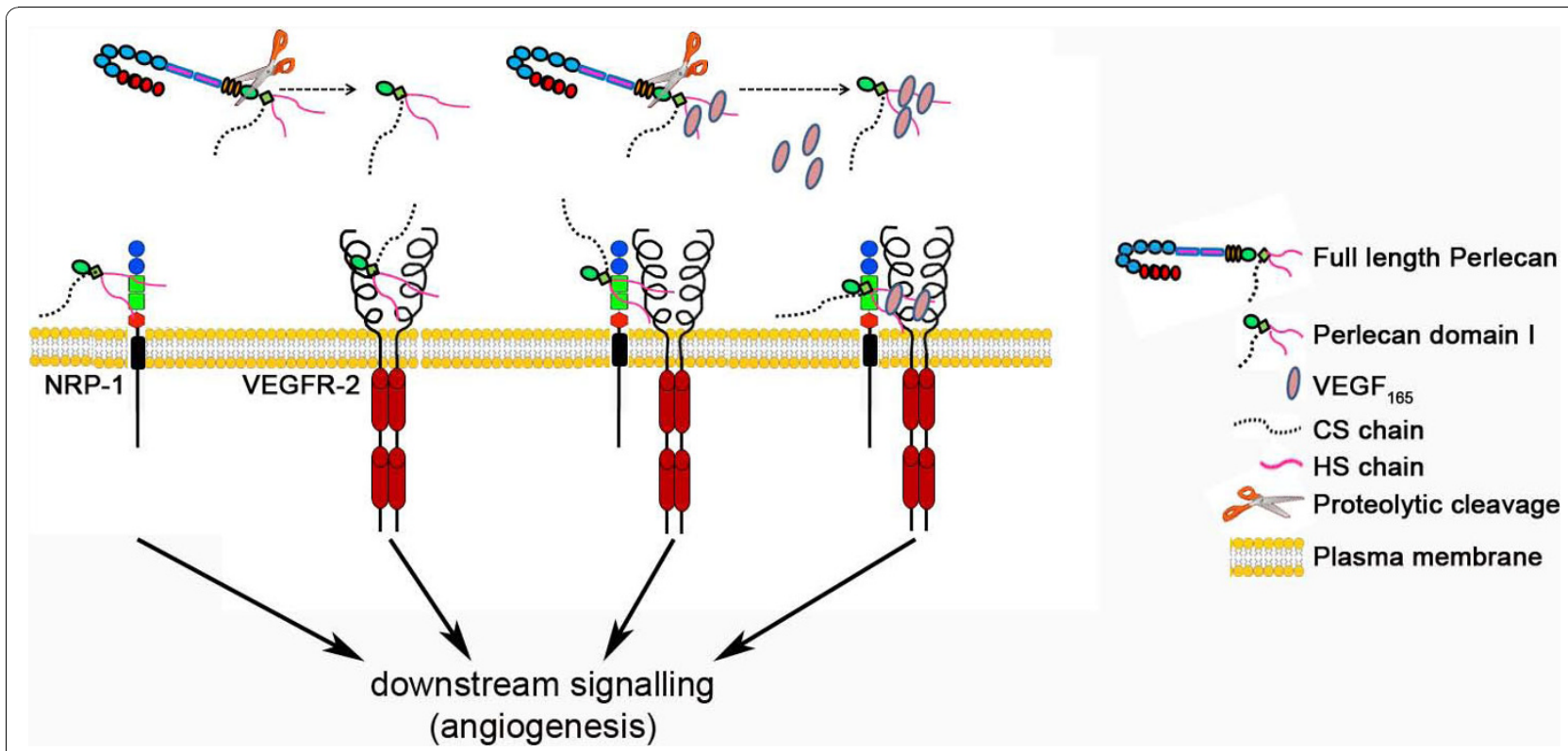

Figure 9 Model: PInDI interactions with the VEGFR-2 signaling complex. N-terminal domain I of perlecan, unbound or bound to VEGF 165 , liberated by proteolytic cleavage (scissors) during extracellular matrix turnover stimulates angiogenesis by direct interactions with: 1) NRP-1; 2) VEGFR-2; and 3) NRP-1 and VEGFR-2. PInDI may enhance VEGF 165 stimulated pro-angiogenic events by stabilizing NRP-1/NEGF ${ }_{165}$ NEGFR-2 interactions.

NJ). Rabbit polyclonal antibodies for phospho- and total- VEGFR-2, and Akt were purchased from Santa Cruz Biotechnology (Santa Cruz, CA) and Cell Signaling (Danvers, MA), respectively. Anti-Perlecan domain I monoclonal antibodies (CSI 001-71) were purchased from the Antibody Shop (Denmark). Anti-Perlecan domain IV antibodies were purchased from Millipore (Temecula, CA). Heparin, heparinase I, II and III and protease free chondroitinase $A B C$ were purchased from Sigma (St. Louis, MO). Heparitinase II enzyme, 3G10 antibodies, and unsaturated heparan/heparin-disaccharide standards were purchased from Seikagaku Corp (Japan).

\section{Cell Culture}

Human bone marrow endothelial cells, provided by Dr. G Almeida-Porada (University of Nevada, Reno, [45]), were cultured in M199 media supplemented with endothelial cell growth supplement (R\&D systems Inc, Minneapolis, MN), 10\% (v/v) heat-inactivated FBS, 1\% (v/v) penicillin/streptomycin, $2 \mathrm{mM}$ glutamax and heparin $(15 \mathrm{U} / \mathrm{ml})$. Cells were sub-cultured when 80 $90 \%$ confluent using $0.05 \%(\mathrm{v} / \mathrm{v})$ trypsin/EDTA. All cultures were maintained at $37^{\circ} \mathrm{C}$ in a humidified $5 \% \mathrm{CO}_{2}$ atmosphere.

\section{Sepharose CL-6B enrichment of Recombinant PInDI}

Recombinant perlecan domain I (PlnDI) was prepared as described previously [17]. PlnDI was enriched by passage through a Sepharose CL-6B column $(1 \times 50 \mathrm{~cm})$, preequilibrated with $50 \mathrm{mM}$ Tris- $\mathrm{HCl}$ buffer, $\mathrm{pH} 8.6$ containing $6 \mathrm{M}$ guanidine- $\mathrm{HCl}$ and $0.5 \mathrm{M} \mathrm{NaCl}$. Fractions were assayed for uronic acid by carbazole method [46], and protein by micro BCA assay (Pierce, Rockford, IL). PlnDI purity was assessed by SDS-PAGE (i.e., Alcian blue and Coomassie blue staining) and Western blotting (see below).

\section{Western Blotting}

PlnDI $(25 \mu \mathrm{g})$, untreated or pre-digested with heparinase cocktail (mixture of heparinases I, II and III, 2.5 Sigma units each) and/or chondroitinase $\mathrm{ABC}$, were electrophoresed on $3-8 \%$ Tris-acetate gels (Invitrogen, CA), then transferred to nitrocellulose. Membranes were probed with anti-PlnDI monoclonal antibodies diluted (1:200) in phosphate buffered saline (PBS) with $0.1 \%(\mathrm{v} /$ v) Tween-20 (PBST), containing 3\% (w/v) BSA. Primary antibodies were detected with anti-mouse IgG secondary antibodies conjugated to peroxidase and visualized by incubation with enhanced chemiluminescence reagent (ECL, GE Healthcare), and exposure to film.

\section{Chondroitinase $A B C$ and Heparinase digestion}

For chondroitinase ABC digestion PlnDI $(25 \mu \mathrm{g})$ was incubated with chondroitinase $\mathrm{ABC}(20 \mathrm{mU})$ in $25 \mu \mathrm{l}$ of $100 \mathrm{mM} / \mathrm{L}$ Tris- $\mathrm{HCl}, \mathrm{pH} 8.0$, containing $30 \mathrm{mM} / \mathrm{L}$ sodium acetate and $0.01 \%(\mathrm{w} / \mathrm{v}) \mathrm{BSA}$ at $37^{\circ} \mathrm{C}$ for 5 hours. For heparinase digestion, PlnDI was incubated 
with a heparinase cocktail in $25 \mu \mathrm{l}$ of PBS containing $4 \mathrm{mM} \mathrm{CaCl}_{2}$ and protease inhibitors for 12 hours at room temperature.

\section{Immunoassays}

Solid phase binding assays were performed as described previously [17]. For solution phase binding assays, PlnDI $(5 \mu \mathrm{g})$ untreated, or pre-digested with a heparinase cocktail and/or chondroitinase $A B C$ was pre-incubated with $20 \mathrm{ng}$ of $\mathrm{VEGF}_{165}$ in PBS containing 3\% (w/v) BSA, or $25 \mathrm{mM}$ HEPES at either $\mathrm{pH} 8.0,7.0$, or 6.0 [37], or $50 \mathrm{mM}$ Tris- $\mathrm{HCl}$ (pH 8.0), PBS (pH 7.0), $50 \mathrm{mM}$ sodium acetate ( $\mathrm{pH}$ 6.0) for $1 \mathrm{hr}$ at room temperature. Samples were subsequently blotted onto nitrocellulose, and blocked. Bound VEGF 165 was detected with antiVEGF $_{165}$ antibodies $(1 \mu \mathrm{g} / \mathrm{ml}$ in $3 \%(\mathrm{w} / \mathrm{v})$ BSA in PBST). Primary antibodies were detected with anti-mouse IgG secondary antibodies conjugated to HRP and visualized as described for Western blotting. Binding was quantified by densitometry and expressed as mean density values (DV) from triplicate assays. Specific binding was determined by subtracting VEGF $_{165}$ background from total bound [18].

\section{Capillary Tube-like Assay}

Growth factor reduced (GFR) Matrigel was added to wells of ice-cold 96 -well plates $(70 \mu \mathrm{l} /$ well $)$ for $6 \mathrm{sec}$ onds. Excess was removed, leaving a thin coating. Plates were incubated for 6 minutes on ice, 20 minutes at room temperature, and finally warmed for 20 minutes at $37^{\circ} \mathrm{C}$. Bone marrow endothelial cells were seeded $(6,500$ cells/well) in serum free RPMI 1640 media containing $1 \%(\mathrm{w} / \mathrm{v})$ penicillin/streptavidin, $2 \mathrm{mM}$ glutamax without growth supplements. After cell attachment, the media was replaced with media containing one or more supplements [i.e., PlnDI $(12.5 \mu \mathrm{g} / \mathrm{ml})$, untreated or predigested with a heparinase cocktail and/or chondroitinase $\mathrm{ABC}$, heparin $\left.(4.0 \mu \mathrm{g} / \mathrm{ml}), \operatorname{VEGF}_{165}(20 \mathrm{ng} / \mathrm{ml})\right]$. For assays conducted in the absence of cell surface heparin sulfate, human bone marrow endothelial cells were cultured for 15 minutes under serum free conditions in RPMI 1640 media supplemented with heparinase cocktail [32]. Such treatments temporarily remove more than $95 \%$ of cell surface HS. Prior to seeding cells were washed twice with RPMI 1640 media.

To quantify tube-like formation cells were fixed (4\% (v/v) paraformaldehyde) after $18 \mathrm{~h}$, stained (SYTO13, Invitrogen, $\mathrm{CA}$ ), then photographed with a SPOT CCD camera affixed to an inverted microscope equipped for epifluorescence. Nine random fields, representing $80 \%$ of each well, were analyzed for three angiogenic parameters: average tube length (defined as three or more cells connected lengthwise, and exceeding $100 \mu \mathrm{m}$ in length; [47], number of tube-like structures, and the number of branch points, using Image J software (NIH). When several tube-like structures merged together or branched, the total length was calculated as the sum of the individual branches. All tube-like formation studies were conducted in quadruplicate wells, and repeated at least three times. Since the outcomes of each angiogenic parameter were similar only average tube length is reported. Note: All supplement concentrations employed herein are optimal, and were determined empirically over a broad range. As a control for enzyme activity, assays were also conducted with supplements containing heat inactivated chondroitinase $\mathrm{ABC}$ and/or heparinase cocktail.

\section{Receptor Phosphorylation studies}

Bone marrow endothelial cells, cultured to $80 \%$ confluence, were rinsed twice with serum free media, and then cultured for 24 hrs under serum free conditions. Cells were pre-incubated with a heparinase cocktail to remove cell surface heparan sulfate (as described above) then incubated with serum free media containing supplements (PlnDI, VEGFs, and heparin, as described above) for either $0,2.5,5,10$ or 20 minutes. After washing (ice-cold PBS), the cells were lysed [10 mM Tris- $\mathrm{HCl}$, buffer $\mathrm{pH} 7.4$ containing $140 \mathrm{mM} \mathrm{NaCl}, 0.2 \%(\mathrm{v} / \mathrm{v})$ Triton X-100, $1.5 \mathrm{mM}$ EDTA, $1 \mathrm{mM} \mathrm{Na}_{3} \mathrm{PO}_{4}, 25 \mathrm{mM} \mathrm{NaF}$, and $1 \mathrm{mM} \mathrm{Na}_{3} \mathrm{VO}_{4}$, protease inhibitors (Roche Diagnostics, Lewes, UK)], and total protein concentrations determined (micro BCA assay). For Western blotting, $30 \mu \mathrm{g}$ of each sample was loaded onto 7\% Tris-acetate gels, electrophoresed under reducing conditions, then transferred onto nitrocellulose. Membranes were probed with anti-phospho-VEGFR-2 (tyrosine residue (Tyr)-951), phospho-Akt, anti totalVEGFR-2, total-Akt, and anti-GAPDH antibodies. Primary antibodies were detected and visualized as described for Western blotting.

\section{Enzyme Linked Immunosorbant Assay}

Recombinant proteins (NRP-1 and VEGFR-2) were allowed to bind overnight $\left(4^{\circ} \mathrm{C}\right)$ in 96 -well plates $(100$ ng/well; Maxi Sorp, Nunc). After several washes and blocking with PBS containing 3\% BSA, PlnDI $(5 \mu \mathrm{g} /$ well) with or without $\mathrm{VEGF}_{121}, \mathrm{VEGF}_{165}$, or heparin [0.01-1000 $\mu \mathrm{g} / \mathrm{mL}]$ was added. After $2 \mathrm{~h}$, and several washes with PBS containing 0.05\% Tween 20, the plates were incubated with anti-PlnDI antibodies (1:500 dilution) for $1 \mathrm{~h}$. Primary antibodies were detected with anti-rabbit IgG secondary antibodies conjugated to HRP $(1: 8000)$. Each well was subsequently incubated with tetramethylbenzidine (KPL; $100 \mu \mathrm{l} /$ well) for $10 \mathrm{~min}$ under gentle agitation. Color development was stopped with $50 \mu \mathrm{L}$ of $0.5 \mathrm{~N} \mathrm{H}_{2} \mathrm{SO}_{4}$. Binding was quantified by measuring absorbance at $450 \mathrm{~nm}$. Unless indicated, all incubations were performed at room temperature. 


\section{Monosaccharide analysis}

As done previously [46], PlnDI $(20 \mu \mathrm{g})$ was hydrolyzed with $4 \mathrm{M} \mathrm{HCl}$ at $100^{\circ} \mathrm{C}$ for $6 \mathrm{~h}$, then dried in a SpeedVac. Residues were dissolved in HPLC grade water then analyzed on a CarboPac PA1 high $\mathrm{pH}$ anion-exchange column $(4 \times 250 \mathrm{~mm})$ using Dionex BioLC HPLC coupled to a pulse amperometric detector.

\section{Disaccharide composition analysis of GAG chain}

As done previously [48], CS disaccharides, released from PlnDI $(20 \mu \mathrm{g})$ following digestion with chondroitinase $\mathrm{ABC}[(20 \mathrm{mU})$ in $50 \mu \mathrm{l}$ of $100 \mathrm{mM}$ Tris- $\mathrm{HCl}, 30 \mathrm{mM}$ $\mathrm{NaOAc}, \mathrm{pH} 8.0$, containing $0.01 \%(\mathrm{w} / \mathrm{v}) \mathrm{BSA}$ at $37^{\circ} \mathrm{C}$ for $5 \mathrm{~h}$ ] were analyzed by HPLC on the $4.6 \times 250 \mathrm{~mm}$ amine-bonded silica PA03 column. Unsaturated HS disaccharides released from PlnDI following digestion with heparinase cocktail were analyzed as above. Commercially prepared bovine tracheal CS disaccharide standards $(\Delta \mathrm{Di}-0 \mathrm{~S}, \Delta \mathrm{Di}-4 \mathrm{~S}$ and $\Delta \mathrm{Di}-6 \mathrm{~S})$, and unsaturated heparan/heparin-disaccharide standards were used to determine standard migration positions and for quantitation.

\section{Statistical analysis}

All experiments were conducted in triplicate, repeated at least three times, and analyzed by two-tailed paired Student's $t$-test using GraphPad Prism version 5.0 for Windows (San Diego California USA). Differences were considered significant at $P<0.05$. All results are presented as means \pm standard error of the mean.

\author{
Abbreviations \\ CS: chondroitin sulfate; GAG: glycosaminoglycan; HSPG: heparan sulfate \\ proteoglycan; HS: heparan sulfate; NRP-1: Neuropilin 1; PInDI: recombinant \\ perlecan domain I; VEGF: vascular endothelial growth factor; VEGFR-2: \\ vascular endothelial growth factor receptor-2; p-VEGFR-2: phosphor-VEGFR-2; \\ t-VEGFR-2: total-VEGFR-2.
}

\section{Acknowledgements and Funding}

We sincerely thank Drs. Daniel D. Carson and Timothy Ritty for their critical reading of the manuscript. We are thankful to Dr. Channe D. Gowda for providing access to instrumentation to facilitate carbohydrate analysis. We also thank Ananya Das for her secretarial assistance.

This work was supported in part by Dean's Feasibility Grant from the Penn State College of Medicine and NIH R03 AR054915 (to R.R. Gomes), and Orthopedic Research \& Education Foundation Grant and Arthritis Foundation Grant (to A. Muthusamy). C.R. Cooper was supported in part by the National Foundation for Cancer Research Metastasis Center Grant at University of Alabama-Birmingham and funds from the Center for Translational Cancer Research.

\section{Author details}

${ }^{1}$ Department of Orthopaedics and Rehabilitation, Penn State College of Medicine, Hershey, Pennsylvania 17033, USA. ${ }^{2}$ Department of Biological Sciences, Center for Translational Cancer Research, University of Delaware, Newark, Delaware 19716, USA.

\section{Authors' contributions}

AM performed all experiments described herein. RRG conceived the study, and participated in its design and coordination. All the authors contributed equally to data analysis, interpretation, and communication of the findings. All authors have read and approved the final version of the manuscript.

Received: 30 April 2010 Accepted: 3 November 2010

Published: 3 November 2010

\section{References}

1. lozzo RV: Basement membrane proteoglycans: from cellar to ceiling. Nat Rev Mol Cell Biol 2005, 6(8):646-656.

2. Noonan DM, Fulle A, Valente P, Cai S, Horigan E, Sasaki M, Yamada Y, Hassell JR: The complete sequence of perlecan, a basement membrane heparan sulfate proteoglycan, reveals extensive similarity with laminin A chain, low density lipoprotein-receptor, and the neural cell adhesion molecule. J Biol Chem 1991, 266(34):22939-22947.

3. Murdoch AD, Dodge GR, Cohen I, Tuan RS, lozzo RV: Primary structure of the human heparan sulfate proteoglycan from basement membrane (HSPG2/perlecan). A chimeric molecule with multiple domains homologous to the low density lipoprotein receptor, laminin, neural cell adhesion molecules, and epidermal growth factor. J Biol Chem 1992, 267(12):8544-8557

4. Bix G, lozzo RV: Novel interactions of perlecan: unraveling perlecan's role in angiogenesis. Microsc Res Tech 2008, 71(5):339-348.

5. D'Souza S, Yang W, Marchetti D, Muir C, Farach-Carson MC, Carson DD: HIP/ RPL29 antagonizes VEGF and FGF2 stimulated angiogenesis by interfering with HS-dependent responses. J Cell Biochem 2008, 105(5):1183-1193.

6. Zoeller JJ, Whitelock JM, lozzo RV: Perlecan regulates developmental angiogenesis by modulating the VEGF-VEGFR2 axis. Matrix Biol 2009, 28(5):284-291.

7. Neufeld G, Cohen T, Gengrinovitch S, Poltorak Z: Vascular endothelial growth factor (VEGF) and its receptors. FASEB J 1999, 13(1):9-22

8. de Vries C, Escobedo JA, Ueno H, Houck K, Ferrara N, Williams LT: The fmslike tyrosine kinase, a receptor for vascular endothelial growth factor. Science 1992, 255(5047):989-991.

9. Terman Bl, Dougher-Vermazen M, Carrion ME, Dimitrov D, Armellino DC, Gospodarowicz D, Bohlen P: Identification of the KDR tyrosine kinase as a receptor for vascular endothelial cell growth factor. Biochem Biophys Res Commun 1992, 187(3):1579-1586.

10. Millauer B, Wizigmann-Voos S, Schnurch H, Martinez R, Moller NP, Risau W, Ullrich $A$ : High affinity VEGF binding and developmental expression suggest Flk-1 as a major regulator of vasculogenesis and angiogenesis. Cell 1993, 72(6):835-846.

11. Waltenberger J, Claesson-Welsh L, Siegbahn A, Shibuya M, Heldin CH: Different signal transduction properties of KDR and Flt1, two receptors for vascular endothelial growth factor. J Biol Chem 1994, 269(43):26988-26995

12. Gille H, Kowalski J, Li B, LeCouter J, Moffat B, Zioncheck TF, Pelletier N, Ferrara N: Analysis of biological effects and signaling properties of Flt-1 (VEGFR-1) and KDR (VEGFR-2). A reassessment using novel receptorspecific vascular endothelial growth factor mutants. J Biol Chem 2001, 276(5):3222-3230.

13. Soker S, Takashima S, Miao HQ, Neufeld G, Klagsbrun M: Neuropilin-1 is expressed by endothelial and tumor cells as an isoform-specific receptor for vascular endothelial growth factor. Cell 1998, 92(6):735-745.

14. Gitay-Goren H, Soker S, Vlodavsky I, Neufeld G: The binding of vascular endothelial growth factor to its receptors is dependent on cell surfaceassociated heparin-like molecules. J Biol Chem 1992, 267(9):6093-6098.

15. Mamluk R, Gechtman Z, Kutcher ME, Gasiunas N, Gallagher J, Klagsbrun M: Neuropilin-1 binds vascular endothelial growth factor 165, placenta growth factor-2, and heparin via its b1b2 domain. J Biol Chem 2002, 277(27):24818-24825.

16. Gengrinovitch S, Berman B, David G, Witte L, Neufeld G, Ron D: Glypican-1 is a VEGF165 binding proteoglycan that acts as an extracellular chaperone for VEGF165. J Biol Chem 1999, 274(16):10816-10822.

17. Yang WD, Gomes RR Jr, Alicknavitch M, Farach-Carson MC, Carson DD: Perlecan domain I promotes fibroblast growth factor 2 delivery in collagen I fibril scaffolds. Tissue Eng 2005, 11(1-2):76-89.

18. Smith SM, West LA, Govindraj P, Zhang X, Ornitz DM, Hassell JR: Heparan and chondroitin sulfate on growth plate perlecan mediate binding and delivery of FGF-2 to FGF receptors. Matrix Biol 2007, 26(3):175-184 
19. Holmes K, Roberts OL, Thomas AM, Cross MJ: Vascular endothelial growth factor receptor-2: structure, function, intracellular signalling and therapeutic inhibition. Cell Signal 2007, 19(10):2003-2012.

20. Yang W, Gomes RR, Brown AJ, Burdett AR, Alicknavitch M, FarachCarson MC, Carson DD: Chondrogenic differentiation on perlecan domain I, collagen II, and bone morphogenetic protein-2-based matrices. Tissue Eng 2006, 12(7):2009-2024.

21. Costell M, Mann K, Yamada Y, Timpl R: Characterization of recombinant perlecan domain I and its substitution by glycosaminoglycans and oligosaccharides. Eur J Biochem 1997, 243(1-2):115-121.

22. Whitelock JM, Melrose J, lozzo RV: Diverse cell signaling events modulated by perlecan. Biochemistry 2008, 47(43):11174-11183.

23. Govindraj P, West L, Koob TJ, Neame P, Doege K, Hassell JR: Isolation and identification of the major heparan sulfate proteoglycans in the developing bovine rib growth plate. J Biol Chem 2002, 277(22):19461-19469.

24. Tapanadechopone P, Tumova S, Jiang X, Couchman JR: Epidermal transformation leads to increased perlecan synthesis with heparinbinding-growth-factor affinity. Biochem J 2001, 355(Pt 2):517-527.

25. Knox SMC, Stringer S, Melrose J, Whitelock J: Not all perlecans are created equal: interactions with fibroblast growth factor (FGF) 2 and FGF receptors. J Biol Chem 2002, 277(17):14657-14665.

26. Melrose J, Roughley P, Knox S, Smith S, Lord M, Whitelock J: The structure, location, and function of perlecan, a prominent pericellular proteoglycan of fetal, postnatal, and mature hyaline cartilages. J Biol Chem 2006, 281(48):36905-36914.

27. Knox S, Fosang AJ, Last K, Melrose J, Whitelock J: Perlecan from human epithelial cells is a hybrid heparan/chondroitin/keratan sulfate proteoglycan. FEBS Lett 2005, 579(22):5019-5023.

28. lozzo RV: Biosynthesis of heparan sulfate proteoglycan by human colon carcinoma cells and its localization at the cell surface. J Cell Biol 1984 99(2):403-417.

29. Sharma B, Handler M, Eichstetter I, Whitelock JM, Nugent MA, lozzo RV: Antisense targeting of perlecan blocks tumor growth and angiogenesis in vivo. J Clin Invest 1998, 102(8):1599-1608.

30. Aviezer D, Hecht D, Safran M, Eisinger M, David G, Yayon A: Perlecan, basal lamina proteoglycan, promotes basic fibroblast growth factor-receptor binding, mitogenesis, and angiogenesis. Cell 1994, 79(6):1005-1013.

31. Robinson CJ, Mulloy B, Gallagher JT, Stringer SE: VEGF165-binding sites within heparan sulfate encompass two highly sulfated domains and can be liberated by K5 lyase. J Biol Chem 2006, 281(3):1731-1740.

32. Ashikari-Hada S, Habuchi H, Kariya $Y$, Kimata K: Heparin regulates vascular endothelial growth factor165-dependent mitogenic activity, tube formation, and its receptor phosphorylation of human endothelial cells. Comparison of the effects of heparin and modified heparins. J Biol Chem 2005, 280(36):31508-31515.

33. Ono K, Hattori H, Takeshita S, Kurita A, Ishihara M: Structural features in heparin that interact with VEGF165 and modulate its biological activity. Glycobiology 1999, 9(7):705-711.

34. Paulsson M, Yurchenco PD, Ruben GC, Engel J, Timpl R: Structure of low density heparan sulfate proteoglycan isolated from a mouse tumor basement membrane. J Mol Biol 1987, 197(2):297-313.

35. Kokenyesi R, Silbert JE: Formation of heparan sulfate or chondroitin/ dermatan sulfate on recombinant domain I of mouse perlecan expressed in Chinese hamster ovary cells. Biochem Biophys Res Commun 1995, 211(1):262-267

36. Ellis AL, Pan W, Yang G, Jones K, Chuang C, Whitelock JM, Decarlo AA: Similarity of Recombinant Human Perlecan Domain 1 by Alternative Expression Systems. BMC Biotechnol 10(1):66.

37. Goerges AL, Nugent MA: Regulation of vascular endothelial growth factor binding and activity by extracellular pH. J Biol Chem 2003, 278(21):19518-19525.

38. Farach-Carson MC, Carson DD: Perlecan-a multifunctional extracellular proteoglycan scaffold. Glycobiology 2007, 17(9):897-905.

39. Olsson AK, Dimberg A, Kreuger J, Claesson-Welsh L: VEGF receptor signalling-in control of vascular function. Nat Rev Mol Cell Biol 2006, 7(5):359-371.

40. Dougher AM, Wasserstrom H, Torley L, Shridaran L, Westdock P, Hileman RE, Fromm JR, Anderberg R, Lyman S, Linhardt RJ, et al: Identification of a heparin binding peptide on the extracellular domain of the KDR VEGF receptor. Growth Factors 1997, 14(4):257-268.
41. Soker S, Fidder H, Neufeld G, Klagsbrun M: Characterization of novel vascular endothelial growth factor (VEGF) receptors on tumor cells that bind VEGF165 via its exon 7-encoded domain. J Biol Chem 1996, 271(10):5761-5767.

42. Levitin F, Stern O, Weiss M, Gil-Henn C, Ziv R, Prokocimer Z, Smorodinsky NI, Rubinstein DB, Wreschner DH: The MUC1 SEA module is a self-cleaving domain. J Biol Chem 2005, 280(39):33374-33386.

43. Whitelock JM, Murdoch AD, lozzo RV, Underwood PA: The degradation of human endothelial cell-derived perlecan and release of bound basic fibroblast growth factor by stromelysin, collagenase, plasmin, and heparanases. J Biol Chem 1996, 271(17):10079-10086.

44. d'Ortho MP, Will H, Atkinson S, Butler G, Messent A, Gavrilovic J, Smith B, Timpl R, Zardi L, Murphy G: Membrane-type matrix metalloproteinases 1 and 2 exhibit broad-spectrum proteolytic capacities comparable to many matrix metalloproteinases. Eur J Biochem 1997, 250(3):751-757.

45. Almeida-Porada G, Ascensao JL: Isolation, characterization, and biologic features of bone marrow endothelial cells. J Lab Clin Med 1996, 128(4):399-407.

46. Muthusamy A, Achur RN, Valiyaveettil M, Madhunapantula SV, Kakizaki I, Bhavanandan VP, Gowda CD: Structural characterization of the bovine tracheal chondroitin sulfate chains and binding of Plasmodium falciparum-infected erythrocytes. Glycobiology 2004, 14(7):635-645

47. Liu Y, Sainz IM, Wu Y, Pixley R, Espinola RG, Hassan S, Khan MM, Colman RW: The inhibition of tube formation in a collagen-fibrinogen, three-dimensional gel by cleaved kininogen ( $\mathrm{HKa}$ ) and HK domain 5 (D5) is dependent on Src family kinases. Exp Cell Res 2008, 314(4):774-788.

48. Achur RN, Muthusamy A, Madhunapantula SV, Bhavanandan VP, Seudieu C, Channe Gowda D: Chondroitin sulfate proteoglycans of bovine cornea: structural characterization and assessment for the adherence of Plasmodium falciparum-infected erythrocytes. Biochim Biophys Acta 2004, 1701(1-2):109-119.

doi:10.1186/1471-2091-11-43

Cite this article as: Muthusamy et al: Soluble perlecan domain i enhances vascular endothelial growth factor-165 activity and receptor phosphorylation in human bone marrow endothelial cells. BMC Biochemistry 2010 11:43.

\section{Submit your next manuscript to BioMed Central and take full advantage of:}

- Convenient online submission

- Thorough peer review

- No space constraints or color figure charges

- Immediate publication on acceptance

- Inclusion in PubMed, CAS, Scopus and Google Scholar

- Research which is freely available for redistribution

Submit your manuscript at www.biomedcentral.com/submit
C Biomed Central 